\title{
BEGRAFNISGEBRUIKE IN VERLEDE EN HEDE
}

\author{
Prof. dr. L. Roeleveld \\ (Regsfakulteit Universiteit van Durban-Westville)
}

\section{Algemeen}

Begrafnisgebruike weerspieël dikwels die kulturele en godsdienstige gevoelens van die betrokke volksgroep. ${ }^{1}$ In die volgende word gegewens uit die praktyk van ons Christelike voorgeslag verwerk wat ek by navorsing vir ander doeleindes op die spoor gekom het. ${ }^{2}$

Die toetsing van die Skrifgebruik soos ek dit in die bronne aangetref het, laat ek graag aan meer bevoegde lesers oor.

\section{Praktyk in die 14e en 15e eeu}

In die $14 \mathrm{e}$ en $15 \mathrm{e}$ eeu, voor die Reformasie, was die sorg vir die oorledenes in Nederland in die algemeen soos volg.

Op die dag van die begrafnis is die lyk in die kerk gebring en is daar ,gepresenteer', ook al is dit in 'n klooster begrawe, omdat die parogiekerk gevrywaar moes word teen finansiële skade. Die uitvaart het geskied in ooreenstemming met die stand van die gestorwe persoon. Agter die lyk is dikwels louriertakke gedra, omdat 'n gestorwe Christen as 'n oorwinnaar in die stryd van die aardse lewe beskou is. Sy uitvaart het daarom die karakter van 'n triomftog gedra. Aan die teraardebestelling gaan die lykmis vooraf. By die gang na die graf lees die priester sy ,miserere' (Ps. 51). Met die lees van Ps. 139 en enige gebede het die diens geëindig.

Die kiste was van hout of steen. Arme dooies is soms eenvoudig in ' $n$ mat gewikkel. Na die $15 \mathrm{e}$ eeu is net houtkiste gebruik.

Eers is op die kerkhowe begrawe. In die $14 \mathrm{e}$ en $15 \mathrm{e}$ eeu word begrawe in die kerk meer gewoon. Die grafte in die ,koor van onse liewe vrou' was die duurste.

Op die uitvaart volg die ,troostelbier' by liede van geringe stand, die lykmaal by aansienlikes. In die $15 \mathrm{e}$ eeu en later is strenge bepalings afgekondig teen die gewoontes, omdat nie selde vegpartye en dronkenskap die einde was.

Vir sielemisse is deur rykes en armes soveel moontlik gesorg. ${ }^{3}$

\section{Kerklike karakter van die Rooms-Katolieke begrafnis}

'n Rooms-Katolieke begrafnis geskied onder leiding van die priester en omvat:

1. die afhaal van die lyk van die sterfhuis om dit na die kerk te bring;

2. die uitvaart, d.i. die requiemmis, voorafgegaan deur die „getydes” vir die oorledene en gevolg deur die seëning van die stoflike oorskot;

3. die absolute (of absolusie), 'n gebed van die priester tot kwytskelding van sondes, en die oorbrenging na 'n Rooms-Katolieke kerkhof; 
4. die eintlike begrafnis in gewyde aarde.

Hierdie kerklike begrafnis word gegee aan almal wat altans uiterlik in vrede met die kerk gesterf het. Die graf is 'n rusplek vir die liggaam, wat eenmaal daaruit sal verrys. Die liggaam was die tempel van Gods inwoning en is deur sakramente geheilig. Vandaar die eerbied in bewieroking, seëning, omgee deur kerslig en te ruste legging in die skadu van 'n kruis. Blomme word nagelaat omdat mens God in boetvaardigheid moet nader.

Begrafnis van kinders word nie in die roukleur nie, maar in wit gehou. Die gedoopte kind is mos vry van sondeskuld as dit onder die jare van verstandsgebruik ( 7 jaar) sterf. Die kerk bid dan nie om die sielerus van die kind nie, maar om die voorbede van die engele, in wie se geselskap die kind opgeneem is. Die Engelemis word gelees. Die liggaam is in wit gehul en met blomme versier. ${ }^{4}$

\section{Familiekarakter van reformatoriese begrafnis}

Reeds die sinode van Antwerpen 1564 het bepaal dat om alle bygelowighede te vermy by die begrafnis van dooies geen gebede of predikasies gedoen sal word nie. Die lui van klokke, wat by die pousdom gebruiklik was, moet volgens die sinodes van 1574 en 1578 van Dordrecht afgeskaf word. Die lof van die afgestorwenes mag nie verkondig word nie.

' $n$ Kerklike vergadering in Appingedam verbied in 1608 dat die dooies in die kerk gebring word. ${ }^{5}$

Die begrafnis is geen kerklike saak nie, maar 'n familie-aangeleentheid. Die diens het nie 'n amptelike kerkelike karakter nie, ook al gaan die predikant daarin voor. Die breuk met die Roomse leer is volledig en absoluut.

Die kerk se ampsdraers het wel ' $n$ taak om die familie te troos uit die Skrif, maar aan die sieletoestand van die dooie kan niks meer verander word nie. In die Bybel is geen bewys vir die bewering dat die kerk as sodanig hom met die begrafnis besig moet hou nie.

Die Dordtse Kerkorde van 1619 bepaal in art. 65 dat lykpredikasies of lykdienste nie ingevoer mag word nie. ${ }^{6}$

Lykverbranding is in stryd met die gereformeerde opvatting, behalwe in geval van nood, soos by besmetlike siektes. ${ }^{7}$

\section{Begrafnisversorging deur gildes en fondse}

\subsection{Holland}

5.1.1. Doel van gildes: Die gildes was vereniginge van persone wat dieselfde vak beoefen en wat hul gemeenskaplike belange bevorder het, maar ook om uiting te gee aan 'n gevoel van gemeenskap, van by mekaar behoort in die algemeen. Hulle het soos die hedendaagse vakverenigings dikwels na politieke mag en invloed gestreef en probeer om die stadsregerings te beïnvloed. In Holland het dit gedeeltelik resultaat gehad in die stad Dordrecht, maar nêrens elders nie. Eintlik was daardie strewe net merkbaar in tye van onrus en dit was dikwels net beperk tot eie sake soos in loonkwessies. 
In Holland was die gildes onder toesig van die stadsbesture. Hul reglemente en wysigings moes vooraf deur daardie besture goedgekeur word en die burgemeesters kon dus verhoed dat die besture hul met die staatkunde sou bemoei. In Leiden was dit die plaaslike gereg, wat hom met hierdie goedkeurings besig gehou het, soos ook later met die goedkeuring van andere fondse.

5.1.2. Regte en pligte van gildebroeders: As iemand as gildebroeder aangeneem is, het hy deel aan die regte en verpligtings van die gilde. Die pligte bestaan in gehoorsaamheid aan stads- en gildebestuur, in deelneming aan samekomste, in onderlinge bystand by siekte en begrafnis en so meer. By al hierdie sake het die gildebestuur die leiding geneem en aan die lede wat in versuim is boetes opgelê. Die glldes het verhoed dat die mededinging te groot was, dat die pryse vir hul produkte te laag sou wees en het ook gesorg, dat daar 'n minimum standaard kwaliteit vir die produkte was. Ook die vakopleiding het hulle behartig. Die bestuurslede van die gilde heet ,overliede' of ,dekens'; die gildekneg of bode was ook die kastelein van die gilde.

5.1.3. Invloed van die Reformasie: Met die val van die Katolieke Kerk verdwyn die kerklike karakter van die gildes, al bly die ou heilige name nog in gebruik. Van nou af kan roomse en protestante almal lid van die gilde word, maar die invloed van die gereformeerde staatskerk het dikwels so ver gegaan, dat net lede van die staatskerk daartoe kon behoort.

5.1.3. Begrafnispligte: Die pligte van die gildebroeders vir die begrafnisse is dikwels sleg nagekom. Dit was dikwels 'n groot sorg om hulle in behoorlike roukleding by mekaar te kry. Hulle het dikwels in gewone of selfs in gekleurde klere verskyn en hul min gesteur aan die vermanings van die gildekneg wat hulle kom oproep, en aan die oorliede, wat die boetes hef. Hulle het liewer die boetes betaal as om hul werk of nering vir die bywoning van 'n begrafnis te versuim. Aan die einde van die $17 \mathrm{e}$ eeu was dit moeilik om die draers uit die lede van die gilde byeen te bring. Die lede het ook bedank vir die eer om begrawe te word met die kleed van die gilde op die baar. Tog was die lykkleed van swaar swart laken met franje en die skilde van suiwer silwer. Maar dit het geld vir die gildekas gekos en vir baie was dit die saak nie werd nie. Daar is nog baie gilde-begrafnispennings bewaar, wat dié broeders by daardie plegtighede as bewys vir hul reg om daar te wees moes saambring.

5.1.4. Onderlinge hulp': 'n Belangrike deel van die inkomste van die gildes is bestee aan armversorging. Uit die vir daardie doel gestigte armebosse, wat afsonderlike regspersone was, het soms 'n stelsel van ouderdoms-, ongevalle- en siekteversekering gegroei. Die broeders moes om lid te word inleggeld betaal en 'n jaarlikse bydrae. By hierdie armebosse kom die aloue broederskapsbeginsel nog goed uit, nie net omdat dit om 'n gemeenskaplike belang gaan nie, maar ook omdat daar verpligtings bestaan het soos om volgens bepaalde beurtlyste by sieke gildebroeders te waak, by sterfgevalle die nodige 
liefdedienste te bewys en om dan as draers op te tree.

Die materiële welvaart van die lede gaan eweseer die gilde ter harte. Siekebroeders was, solank hulle nie kon werk nie, uit die gildekas ondersteun. Oorly hulle dan kom die gilde die nagelate betrekkinge te hulp in die bestryding van die begrafniskoste. Daartoe bestaan gewoonlik ' $n$ aparte kas. So ' $n$ bos wil niks anders as 'n siekeen begrafnisfonds wees nie. Geselle en meesters van dieselfde ambag kon so 'n kas stig. ${ }^{10}$ Maar ook dikwels genoeg gaan groepe van persone daartoe oor, wat heeltemal nie in die uitoefening van 'n beroep onderling verbonde is nie. ${ }^{11}$ Byvoorbeeld, mense wat as inwoners van 'n Hollandse stad afkomstig was van 'n buitelandse plek of streek. ${ }^{12}$ Ook het sieke-, weduwee- en dodebosse bestaan, waartoe ' $n$ ieder kon toetree. ${ }^{13}$ Al hierdie soorte bosse word dikwels gildes genoemd, maar dit beteken dan net vereniging. Daar word ook dikwels van beurse, sosieteite, kompakte, konfrerieë of broederskapppe gespreek.

Mens moet onderskei tussen vrywillige en onvrywillige bosse: ${ }^{14}$ in die eerste geval was die gildebroeders vry om toe te tree, in die ander nie. ${ }^{15}$

Op die duur word die verleen van bystand in geval van siekte en dood die hoofdoel van die gilde. Orals in die latere jare van die $18 \mathrm{e}$ eeu vind mens tekene van hul finansiële agteruitgang, dikwels veroorsaak deur 'n groot aantal siekte en sterfgevalle. Maar veral die pensioen aan oues van dae skyn op die duur te veel te gewees het vir die geldelike draagvermoë van die bosse. ${ }^{10}$

5.1.5. Begrafnisgebruike volgens reglementsbepalinge: Die reglementsbepalinge van gildes en fondse gee insig in die begrafnisgebruike.

Gildelede het na die lykdra 'n half vat bier in die huis van die kneg van die gilde gekry. Die beurs betaal aan die kneg vir bier, tabak en pype agt gulden vir elke draer. Op die begrafnis mag nie gevloek word nie; die broeders moet in swart op die begrafnis kom en die draers ook met 'n bef. ${ }^{17}$

Die Timmerliedegilde het 'n doodskleed vir die baar gehad om dit by die begrafnis van hul lede en hul weduwees te gebruik. Die lykdraers moes 'n behoorlike rougewaad aantrek. ${ }^{18}$

'n Ander reglement vermeld ook die gebruik van 'n geplooid kleed en van bier. Die draersplig van die lede is by toerbeurt vervul. ${ }^{19}$

Behalwe bier is ook koekies en vye aan die draers gegee. ${ }^{20}$

Openbare versorgingsinstellings soos Gods- en weeshuise was verplig om die begrafnis van die versorgde persoon te reël..21

Ekstra koste moes betaal word vir 'n eikehoute kis en begrafnis in die kerk. Ander begrafniskoste was die aflê van die lyk, die fooi van die lyksdraers, die salaris van die koster, roukleed en mantels, bier, wittebrood, kaas, koffie en suiker. ${ }^{22}$

Dit het voorgekom dat 'n lang stoet van treurendes die lyk na die graf vergesel. Die mense moes 'n roumantel en bybehorende hoed dra. Die stad het honderde daarvan besit en hul verhuur, terwyl die winste daarvan aan die weeshuis afgestaan is. ${ }^{23}$

In 'n geval is voorgeskryf dat lykbesorging nie op Sondag mag 
plaas vind nie, behalwe by uiterste noodsaak. ${ }^{24}$

In 'n ander geval vermeld 'n reglement as die taak van die ,vinders', dit is die lede van die fonds wat om toerbeurt as inkasseerders van die kontribusie optree, dat hulle elke Sondag van 10-12 uur in die kamer van die beurs moet wees om die kontribusie te ontvang. ${ }^{25}$

\subsection{Duitsland ${ }^{26}$}

5.2.1. Dieselfde ontwikkeling as in Holland. Die begrafnisfondse in Duitsland het ook uit die gildes ontstaan. Die eerste is in Duitsland in 1293 opgerig. Die gildes was broederskappe wie se lede mekaar help by ongevalle, brand, skipbreuk, dood, ens. en waar ook uitings is van geselligheids-, godsdienstige en politieke verbondenheid.

Heeltemal anders is die ,Zünfte'. Daar is verpligtings en daartoe behoort die begrafnishulp. Afwesigheid sonder goeie rede is strafbaar.

Al hierdie instellings berus op die gedagte van die naasteliefde, van die beroepsmatige saamstaan onder die motto: een vir almal, almal vir een. Hoewel mens spreek van Christelike naasteliefde, word glad nie die altruïsme sonder aansien van die persoon bedoel nie, maar dit vir mekaar instaan binne die bepaalde kring van gilde of broederskap. Niemand kom sy verpligting na uit medelyde of naasteliefde nie, maar om in die gegewe geval dit terug te ontvang.

Maar dit is tog ook die draende grondidee van die versekeringswese, dat almal daarby aanspraak en steun vind wat hul tydig aangesluit het, nie egter hulle wat sorgeloos van die een dag in die ander leef tot dit te laat is nie. Ook die verpligting tot deelneming het dieselfde bedoeling gehad. Toe die laste te swaar word en die jongeres veral dit as te drukkend ervaar het, is die gesag van die ,Zünfte' afgebrokkel en ten slotte is hulle dikwels deur vrywillige broederskappe vervang.

Aan die einde van die $17 \mathrm{e}$ eeu is baie kasse opgerig wat 'n kortstondige bestaan gehad het omdat 'n juiste berekening van die sterfterisiko ontbreek het en die gelde nie op die regte manier belê is nie.

5.2.2. Godsdienstige motiewe: Die pre-ambules van die reglemente van die kasse het 'n sterk godsdienstig karakter. Daar word melding gemaak van die kortstondigheid van die lewe en die dood as straf vir die sondes. Ook baie Bybeltekste word aangehaal soos Pred. $7:$ 9, Matt. $10: 22$, Openb. $2: 10$, Luk. $9: 62$, Hebr. $12: 1$, 2 Tim. $6: 18,2$ Kon. $20: 1$, Sirag $8: 39$, Gen. $3: 9$, Gen. $4: 8$, Gen. 4 : 26, Matt. 15 : 13. In die voorrede van die ,Sämtliche Christlöbliche Leichen-Societät' word genoem: 1 Kor. $15: 31$, Job $7: 8$, Wysheid $5: 10$, Ps. $103: 15$, 16, Wysheid $2: 4$, Gen. $3: 39$, 2 Sam. $14: 14$, Joh. 9 : 11, Gen. $3: 19$, Mark. $16: 26$, Gen. $25: 31$, Ps. 39 : 5, 2 Tim. $6: 7$, Fil. $1: 23$, Job $7: 2$, Ps. $142: 8$, Ps. $34: 21$, Eseg. $37: 12$, Jes. $66: 14$, Joh. $17: 28$, Hand. $25: 3$, Ps. $17: 5$, Hand. 19 : 5. 
geneem. Hieruit blyk hoe sterk die bevolking destyds aan die kerk verbonde was. In die besonder in Roomse streke was dit altyd gebruik dat verenigings van allerlei aard en gildes aan die kerklike feeste en veral aan prosessies declgeneem het en hul vaandels in die kerk vir wyding ingedra het. Met die evangeliese kerke het sulke hegte verbinding nie bestaan nie en hul invloed op die lidmate was ook geringer. Toe in Hamburg die Lutherse godsdiens in 1673 staatsgodsdiens word, was dit vir die Roomse noodsaaklik om hul eie broederskap op te rig, wat die gestorwe lidmate in kerklik gewyde grond kon begrawe. Daar was ook sterftekasse wat aan 'n kerklike gemeente verbonde was. 'n Roomse kas verseker byvoorbeeld die uitvaart uit die sterf- of lykehuis, die begeleiding van die lyk deur die geestelikes van die sterfhuis tot op die kerkhof, die grafrede en die lees van drie heilige misse. Dat so 'n kerklike sterftekas geen dienste verseker en geen sterftegeld betaal nie, is die saak van die lidmate. By 'n Roomse broederskapskas gaan dit daarom dat die kerklike voorskrifte nageleef word en dat die kerk dus tot sy reg kom. In 1927 bepaal 'n vereniging dat iemand wat die Roomse Kerk verlaat sy lidmaatskap verbeur en sy aansprake verval. Dit is ook die geval met iemand wat nie volgens die Roomse seremonie begrawe kan word nie.

\section{Ander begrafnisgebruike in Holland ${ }^{27}$}

\subsection{Bidder}

Die vernaamste taak van die bidder was om die familie en vriende van die oorledene van sy dood en begrafnis in kennis te stel. 'n Voorbeeld daarvan is die volgende:

Die burgemeesters van 's-Gravenhage het op 28 Februarie 1695 'n bode van Scheveningen as bidder vir begrafnisse op die dorp aangestel met insluiting van ander persone volgens die betrokke ordonnansie. Hy is deur vooraanstaande persone daartoe voorgedra en sou sy dienste vir die diakonie, die gasthuise en die weduwees verniet verrig. ${ }^{28}$

Ek onthou uit my jeug dat toe die gebruik in Scheveningen nog in ere was.

\subsection{Begrafnispenninge}

Interessant is die gebruik dat die familie van die oorledene begrafnispenninge uitreik aan sy gildebroeders, wat by die begrafnis teenwoordig was. Meestal was hul gegraveer en van lood, soms egter van edeler metaal en beter maaksel. ' $n$ Voorbeeld is die grote begrafnispenning van die Groot Kramersgilde met 'n middellyn van $7 \mathrm{~cm}$. Aan de voorkant is 'n afbeelding van ' $\mathrm{n}$ doodskop in die midde, wat op 'n tafeltjie lê waarop ' $n$ monogram I HS. Om die doodskop is 'n weegskaal. Uit die donker wolke aan die bokant straal lig na onder. Die woorde MORS JUSTITIA COELI. DER VROMEN DOOTDEN WECH DES HEEMELS. An: 1661. Aan die agterkant 'n groot anker wat aan 'n ketting uit ligte wolke hang, waaruit lig na onder straal. Voorts 'n wimpel, waarop $\mathrm{N}^{\circ}$. Die 
woorde is IN DOMINO SPERANTI MISERICORDIA. DIE GODT VERTROUT VERKRYCHT GENADE. ${ }^{29}$

\subsection{Eiendom van graftes}

Bekend is die koop deur Abraham van 'n graf vir sy vrou Sara.

Die Romeine het verbied om die dooies in die stede te begrawe en het hul private graftes buite die stad in die platteland gehad. Die familiegraftes was verhandelbaar en kon geërf word.

Volgens die Kanonieke reg was graftes nie verhandelbaar nie. $\mathrm{Na}$ die Reformasie was dit wel die geval en was eiendom van graftes in die kerke bestaanbaar. ${ }^{30}$

\subsection{Testamentêre beskikking}

De Groot vermeld, dat ieder bevel mag doen van die begrawing van sy liggaam binne die grense van die goeie sedes. ${ }^{31}$ 'n Ter dood veroordeelde het egter toestemming van die owerheid nodig. Persone wat in 'n tweegeveg gesterf het, moes stil begrawe word. ${ }^{32}$

Op grond van vermelde reël is dus toetreding tot 'n begrafnisfonds, wat uitvoering van die begrafnis volgens die voorskrifte van die fonds tot gevolg het, wettig.

\section{5. ,Voor de baar uitgaan,}

Die weduwee wat voor die baar uitgaan alleen met haar alledaagse klere, is bevryd van die skulde wat gedurende die huwelik gemaak is. ${ }^{33}$ Volgens die Rechtsboek van Den Briel lê sy dan die sleutels op die kis en gaan in geleende klere voor die baar die sterfhuis uit. Vervolgens doen sy op simboliese wyse (deur halm werping) afstand van die gemeenskap. ${ }^{34}$ In Zierikzee lê die vrou haar opperste kleed en riem neer as die man begrawe word, waardeur sy afstand doen. ${ }^{35}$

\section{Begrafnisgebruike in Suid-Afrika}

\subsection{Kompanjiestyd}

Baie interessant is, wat Anna de Villiers ${ }^{30}$ vermeld omtrent begrafnisgebruike uit vervloë dae. Hulle is op Nederlandse lees geskoei en as 'n belangrike plegtigheid beskou. Die begrafnisondernemer, of aanspreker, soos hy genoem is, het familie en vriende van die oorlye in kennis gestel, en die bidder het persoonlik omgegaan cn mense na die begrafnis uitgenooi. Aan die Kaap het die koster van die kerk van oudsher die begrafnis gelei, maar hy is soms as aanspreker betitel.

Die hele huisgesin tesame met die slawe is in swart geklee as teken van rou, nogal 'n kosbare onderneming as dit goed gedoen moes word. So vertel C. Graham Botha, vroeër hoofargivaris, van 'n Kaapse burger wat vroegtydig die nodige vir so 'n gebeurlikheid in sy groot gesin uit Holland bestel het. Die bestelling het die volgende behels: 1 stuk drap de dames, d.i. roumateriaal vir vroueklere; 1 stuk swart krip vir manshoede, krip vir vrouehoede en sakdoeke, 1 
dosyn swart gebreide dameshandskoene, 1 dosyn swart seemsleermanshandskoene, $2 \frac{1}{2}$ dosyn waaiers vir 'n begrafnis, 2 dosyn swart skoengespes, 1 dosyn swart kniegespes, 24 dosyn swart dubbel hempknopies, 2 dosyn stukke swart roulint vir hoede, 1 dosyn swart nekgespes, ens.

Enkele van hierdie artikels het verduideliking nodig: die swart waaiers is bestel met die oog op 'n moontlike snikhete somerdag vir die begrafnis en met soveel swaar rouklere kan dit hoogs nodig wees; daarby moet onthou word dat die $18 \mathrm{e}$ eeu by uitstek die eeu van die waaier was. Die kniegespe was nodig vir die kniebroeke wat in die $18 \mathrm{e}$ eeu deur alle mans gedra is. Onthou moet word dat langbroeke of sansculotte eers uit die Napoleontiese tydperk dateer. Trouens, die manskleredrag van die $18 \mathrm{e}$ eeu was minstens net so swierig en weelderig soos dié van die vroue. So het die mans by geleentheid van 'n begrafnis, veral die familielede, lang breë kripslippe gedra wat soms selfs op die grond gesleep het. Hierdie slippedraers sien ons nog in ons eie tyd op 'n staatsbegrafnis van 'n vooraanstaande lid van die publiek.

'n Ander gewoonte het daaruit bestaan dat muntstukke op die oë van die oorledene geplaas is, en nie lank gelede nie, toe uitgrawings in Kaapstad gedoen is op die plek waar 'n ou begraafplaas vroeër gewees het, het die werksmense baie kiste gevind waarin daar geldstukke was.

Die gebruik om vooraanstaande persone binne die Groote Kerk in Kaapstad te begrawe het tot 1835 voortgeduur; dit het 200 gulden gekos en verder moes die besteller 'n behoorlike grafkelder op eie koste laat bou. Daar was ook nog ,huurgraven' wat toen 500 gulden aan 'n vreemdeling wat hier te sterwe gekom het, toegeken kon word, en vir die begrafnis is nog 75 gulden daarvoor toegeslaan, teenoor die 9 gulden wat gevra is om iemand in 'n gewone kerkhof by te lê. Die begrafnis het gewoonlik om vyfuur in die namiddag plaasgevind sodat werksmense dit ook kon bywoon. Voor die einde van die $18 \mathrm{e}$ eeu het daar selfs 'n gewoonte ontstaan om die begrafnisse saans met fakkels in die kerk te hou. Die brandgevaar wat hierdie gebruik meegebring het, was baie groot, maar die eintlike rede waarom hierdie gebruik later verbied is, is omdat daar, wanneer so 'n begrafnis op 'n Saterdagaand binne die kerk moes plaasvind, nie genoeg tyd was vir die messelwerk wat aan die grafkelder gedoen moes word, voordat die erediens die volgende oggend gehou kon word nie. So 'n begrafnis is in 1715 in die Kaap gehou vir die weduwee van kaptein Dominiques Pasques de Chavonnes, en uit die boedelrekening in die Kaapse Weeskamer blyk dat daar een-en-twintig, lantaarndragers' was wat deel van die begrafnisstoet uitgemaak het; hulle getal is bepaal deur die lengte van die stoet wat paarsgewys voortbeweeg het.

Die gebruik van huilebalken wat in Nederland vry algemeen was het in hierdie land nooit juis ingang gevind nie. Hierdie huilebalken is gehuur om as roudraers op te tree en het, soos die woord te kenne gee, onder aanvoering van die aanspreker, op bepaalde oomblikke in die seremonie luidkeels gehuil, en ook deur hul swarte treurmondering met swaar sluiers, kripbande en lang rou- 
gewade probeer om die geleentheid uiterlik meer indrukwekkend te laat voorkom.

Kolbe wat 'n volledige beskrywing van die Kaapse begrafnisse gee, deel mee dat in sy tyd, d.w.s. toe die Van der Stel's hier was, geen plegtigheid by die graf plaasgevind het nie. In 1822 was dit nog so, maar later het hierin verandering gekom. Kolbe vertel ook niks van die groot begrafnismaaltyd wat in die geval van gegoede burgers agterna gehou is nie. Kolbe noem slegs brood en wyn wat voorgesit sou gewees het. Uit die boedelrekeninge van die tyd blyk dat daar soms wel groot klarigheid op hierdie gebied gedoen is. Uit die boedelrekeninge kom daar dikwels by die begrafnisonkoste sulke opgawes voor soos: hoenders, eende, ganse, kalkoene, hamme, rosyne, amandels, olywe, soucys de bolonje, tee, koffie, wyn, bier, brandewyn, koek, brood, kaas, tabak, pype en snuif.

Hoewel al hierdie dinge nie op elke begrafnis aangebied is nie, gebeur dit tot vandag nog dat vriende en familiebetrekkinge dikwels lang afstande moet aflê, soms in groot haas, om 'n begrafnis by te woon, en dat die familie aan huis van die oorledene hul verplig voel om iets aan hul verwante aan te bied voor hulle vertrek huiswaarts; ook het hierdie begrafnismaal dan 'n geleentheid gebied vir die familie om hul ook weer op hoogte te stel van mekaar se welstand en lewensomstandighede. So vertel Adam Tas in 1705 in sy Dagboek dat vyf emmers wyn, een Kaapse ham, drie vet boude gebraaide skaapvleis en drie brode na die begrafnis van sy oom se kneg gestuur is.

Les bes moet ek nog melding maak van 'n ander vreemdsoortige gebruik wat op ' $n$ begrafnis in 1780 afgespeel is. 'n Weduwee het op die begrafnis van haar man wat kort tevore bankrot verklaar is, die sleutel van hul huis op die doodkis geplaas. Sy het reeds die huis verlaat voordat die stoflike oorskot verwyder is, en met hierdie gebaar het sy te kenne gegee dat sy die boedel aan die krediteure oorlaat, en so is die sleutel later deur die aanspreker aan die president van die geregshof oorhandig. Aldus Anna de Villiers.

Die kommissaris-generaal het op 25 Februarie 1793 ernstig gewaarsku teen ,in 't oog loopende pracht en verkwisting' by begrafnisse aan die Kaap. ${ }^{37}$

\subsection{Teenwoordige praktyk}

In die praktyk word nog deur baie vasgehou aan die gedagte dat die begrafnis ' $n$ saak is van die familie in die eerste plek. Die familie tref al die reëlings, hulle bepaal die tyd en plek van die begrafnis, en hulle vra die persoon wat vir hul die leiding moet neem, gewoonlik die eie predikant of ouderling. Om praktiese redes word die diens in die kerk gehou, as dit naby genoeg aan die begraafplek is. Heel dikwels word die diens by die sterfhuis gehou. Hier word uit die Skrif voorgelees, 'n toepaslike woord van vertroosting en vermaning word uitgespreek, en 'n gebed word gedoen. 'n Versie of twee word ook gesing. By die graf is die seremonie kort. Gewoonlik 'n psalmgesang, Skriflesing, gebed en dikwels die Geloofsbelydenis. ${ }^{38}$

Volgens my eie waarneming is 'n verskil tussen die Gerefor- 
meerde praktyk in Nederland en in Suid-Afrika, dat in die laaste geval die lyk nie in die kerkgebou gebring word nie en die lykkis deur die naaste familielede na die graf gedra word.

Die Christelike karakter van begrafnisplegtighede vind sy uitdrukking in reglement van onderlinge hulpverlenings ${ }^{39}$ wat vergelykbaar is met die oud-Hollandse begrafnisfondse. ${ }^{10}$

Die taak van die kneg en bidder van weleer word vervul deur die sekretaris van die begrafnisvereniging. ${ }^{11}$ Selfs bepalings teen dronkeskap, bakleiery, gebruik van onbehoorlike of slegte taal tydens vergaderinge van die begrafnisgenootskap, soos destyds in die gildereglemente, is nog bekend. ${ }^{42}$

1 Omtrent begrafnisgebruike van die Romeine kyk Tafel $\mathbf{X}$ van die Lex XII Tabularum en die uitvoerige aantekeninge van die Glossatore daaromtrent, o.a. vermeld in die Corpus Juris Civilis Romani, uitgawe Gothofredus soos toegelig deur Simon van Leeuwen, 1756, deel II, bl. 753-754.

2 Vgl. my Suid-Afriliaanse lewensversekeringsreg, ongepubliseerde LL.D.proefskrif UOVS, $1977,478 \mathrm{bl}$.

3 J. de Jong, Leerboek voor de geschiedenis van het vaderland, 's-Gravenhage, 1912, I, bl. 97; De Oude Kerk te Scheveningen, 's-Gravenhage, 1960, bl. 34-36.

4 Winckler Prins voor de Vrouw Encyclopaedie, Elsevier, Amsterdam, 1954, I, bl. 343.

5 F. L. Bos, De Orde der Kerk, 's-Gravenhage, 1950, bl. 235-236.

6 Kyk Handelinge $36 e$ Sinodale vergadering van die Gereformeerde Kerk in Suid-Afrika, 1967, bl. 104-125.

7 Handleiding by die Kerkorde van die Gereformeerde Kerk in Suid-Afrika, Potchefstroom, 1966, bl. 397; Sinodaal besluit van die Ned. Geref. Kerk van Natal, 1945, in Kerkorde en Bepalinge, 1967, bl. 217-218; P. Jasperse, Zullen wij onze dooden begraven?, Goes, sonder jaar, 68 bl.

8 P. J. Blok, ,Uit onzen bloeitijd', Schetsen van het Leven onzer Vaderen in de XVIIe Eeuw, ,De Gilden', Baarn, 1910, 39 bl.

9 E. M. A. Timmer, Knechtsgilden en knechtsbossen in Nederland, Arbeidersverzekering in vroegere tijden, proefskrif lettere, Universiteit, Amsterdam, 1913, IXLIII, 202 bl.

10 Timmerluiden, schrijnwerkers en wielemaakers busse, 1707-1925, OudArchief, 's-Gravenhage.

11 Gereformeerde Streepte Baeywerkersbeurs, behorende onder de Fustynhal, binnen de stad Leyden, reglement 1747, Gemeente-Archief, Leiden; De Leydse Geregtigheyt Binnen de Stad Leyden, reglement 1751, GemeenteArchief, Leiden.

12 De Geldersche Beurse binnen de stad Leyden, later genoem het Geldersche Broederschap, 1714-1922, Gemeente-Archief, Leiden.

13 Begrafnisbos de Vrijwillige Liefdebeurs onder de zinspreuk ,In alles ghetrou', opgerig in 1719 Haarlem (die instelling het langer as 200 jaar bestaan).

14 Die woorde ,bus' en ,bos' beteken kenlik metaaldosie met gleuf of ysterkis waarin die bates van die instelling bewaar is.

15 Toetreding tot die ,Weduwe en Weesen beurse binnen Goes' was volgens die reglement van 1773 verplig vir bepaalde personen. Ontleen aan Bouw. 
stoffen voor de geschiedenis van de levensverzekeringen en lijfrenten in Nederland, Amsterdam 1897, bl. 307-320.

16 Vrywillige Algemeene Bos tot Begraffenissen en onderstand van hoogbejaarden boven de zestig jaar oud, onder de zinspreuk Mijn Glas Loopt Ras, Gemeente-Archief, Haarlem.

17 Arts. 22 en 23 van die Baeywerkersbeurs (kyk voetnoot 11).

18 leglement 'Timmerluiden... busse (kyk voetnoot 10 ).

19 Reglement Geldersche Beurse (kyk voetnoot 12).

20 Reglement De Leydse Geregtigheyt (kyk voetnoot 11).

21 Reglement ,In alles ghetrou' (kyk voetnoot 13).

22 Reglement der Societeit opgeregt in Schevening, onder de Zinspreuk ,In tijds gezorgt', Oud-Archief Gemeente 's-Gravenhage.

23 J. Schuurbeque Boeije, De Tontine voor het ,Arme Kinderhuys' te Zierikzee van 1784, De Verzekeringsbode, Weekblad voor Levensverzekering, 16 Maart 1951, bl. 99-100.

24 Reglementswysiging in 1738 Timmerluiden... busse (kyk voetnoot 10).

25 Art. 5 IReglement, In alles ghetrou' (kyk voetnoot 13).

26 Ernst Vesper, Die Sterbekassen in alter nur neuer Zeit, edisie Duncker \& Humblot, Berlin, Schriftenreihe des Instituts für Versicherungswissenschaft an der Universität Köln, 1966, XX, 534 bl.

27 Natuurlyke IIistorie van Holland, derde deel, derde stuk, 19e hoofstuk ,handelende over de Oude en Nieuwe Volkeigene Begraafnis-Plegtigheden der Hollanderen, bl. 1783-2007. Hierdie werk bevat baie meer besonderhede as wat hier vermeld word; dit is aanwesig in die Biblioteek van die Oud-Archief van Delft.

28 J. C. Vermaas, Geschiedenis van Scheveningen, 's-Gravenhage, 1926, I, bl. 114-115.

29 Nederlandsche Historieprenten (1555-1900) Platen-Atlas, samengesteld door G. van Rijn met medewerking van prof. dr. G. W. Kernkamp, Amsterdam, 1910, bl. 120.

30 Simon van Leeuwen, Rooms-Hollands Regt 1.1.9., Censura Forensis, Leiden, 1741, 1.2.1.12.-14.

31 H. de Groot, Inleiding tot de Hollandse Regtsgeleertheid, 2.1.46, slot.

32 De Groot (voetnoot 31), uitgawe Van Apeldoorn, 1939, II, bl. 85.

33 De Groot (voetnoot 31), 2.11.18. Van Apeldoorn (voetnoot 32), bl. 141-142. Van Leeuwen Rooms-Hollands Regt (voetnoot 30), 4.3.13. P. J. Blok, Leidsche Rechtsbronnen uit de Middeleeuwen, Kenningboeken 1434-1542, bl. 298, nr. 400 , bl. $330-331$, nr. 452 , bl. 352, nr. 493.

34 A. S. de Blécourt, Kort Begrip van het Oud-Vaderlandsch Burgerlijk Recht, Groningen, 1952, bl. 96; Bewijsstukken, II, bl. 426-427.

35 Keurboek 1429 in De Blécourt Bewijsstukken II (voetnoot 34), bl. 476.

36 A. de Villiers, Volksgebruike uit vervloë dae, 'n Reeks populêre praatjies wat in die Vrouerubriek van Radio Suid-Afrika uitgesaai is, gepublisee deur die SAUK, sonder jaar, bl. 11-13.

37 T. N. Hanekom, Helperus Ritzema van Lier, Die Lewensbeeld van 'n Kaapse predikant uit die 18e eeu, Kaapstad-Pretoria, 1959, bl. 291.

38 Kyk voetnoot 6 .

39 Die gegewens in voetnote $40-42$ is ontleen aan opgawes volgens die Wet op Onderlinge Hulpverenigings 1956.

40 Die Christelike karakter vind soms uitdrukking in die bewoordinge van die reglemente. Ek noem die volgende voorbeelde: Calvyn Helpmekaarge. 
nootskap Retreat, gestig 6 Desember 1952. Die seèl van die genootskap is binne 'n sirkel 'n kruis wat lig gee, waaronder twee ineengevoude hande, met die woorde CAL. PROT. KERK. ALMAL EEN IN CHRISTUS. Die doel is om sy lede hulp te verleen in tyd van sterfgevalle. Gemeenskaplike Voorsorg en Begrafnisgenootskap Huguenot. Die genootskap is 'n Christelike mensliewende, onderlinge, hulpgewende organisasie. Dienste is heilsaam en onderling en nie profytmakend. Omdat dit dan so is word God die Here as die Hoë Opsiener erken. Die genootskap sal die Regering van die Land te alle tye eerbiedig. By alle Vergaderings sal God die Here geeer en geprys word en in die Openings-gebed sal daar te alle tye vir die Regering en Regeringsowerhede gebid word. Die begrafnisafdeling verskaf begrafnisse sonder dat die lede vir die begrafnis moet betaal of die kis moet koop.

41 Malmesbury Begrafnis Vereniging, gestig in 1892. By 'n sterfgeval sal die naasbestaandes van die oorledene dadelik aan die Sekretaris kennis gee, wanneer hy die nodige voorbereidsels vir die begrafnis sal maak as volg: i. Hy kry alle besonderhede van die naasbestaandes, soos volle naam, ouderdom, ens., ens., van die oorledene. ii. Hy gee die kontrakteur vir die maak van doodkiste kennis. iii. Hy gee die koster kennis van die tyd van begrafnis, en die gee dan aan die lede en publiek kennis. iv. Hy sorg vir die kennisgewing aan die draers deur die koster. v. Hy kry 'n doodsertifikaat van die dokter en 'n begrafnisorder en kry ook grond as die naasbestaandes nie grond het nie, en gee instruksies vir die maak van die graf. vi. Hy sien dat die lykswa in orde is, huur twee motorkarre vir die predikant, draers en oue van dae. vii. Hy gee die predikant kennis van die begrafnis, by afwesigheid van die predikant gee hy kennis aan 'n ouderling. vii. Hy sal die lanfers en handskoene in sy besit hou. Die koster sal sy werk doen onder toesig van die Sekretaris en by versuim van sy pligte kan die Sekretaris iemand anders in sy plek aanstel. Hy stuur namens die bestuur 'n deelnemingskaartjie aan die naasbestaandes van die oorledene. Huur 'n waenhuis vir die Motorlykswa en sorg dat alles in orde is, insluitende reparasies aan die Motorlykswa vir rekening van die Vereniging.

42 Die reglement van die Robertsonse broederlike weldadigheidsgenootskap. opgerig in 1929, bedreig dié gedrag met boete. 